Hydraulic Engineering Repository

Ein Service der Bundesanstalt für Wasserbau

Bromwell, Les; Ying, Kenneth

Correlation of Predicted and Measured Slope Erosion

Verfügbar unter / Available at:

https://hdl.handle.net/20.500.11970/100230

Vorgeschlagene Zitierweise / Suggested citation:

Bromwell, Les; Ying, Kenneth (2010): Correlation of Predicted and Measured Slope Erosion. In: Burns, Susan E.; Bhatia, Shobha K.; Avila, Catherine M. C.; Hunt, Beatrice E. (Hg.): Proceedings 5th International Conference on Scour and Erosion (ICSE-5), November 7-10, 2010, San Francisco, USA. Reston, Va.: American Society of Civil Engineers. S. 1043-1053. 


\title{
Correlation of Predicted and Measured Slope Erosion
}

\author{
Les Bromwell, Sc.D., P.E. ${ }^{1}$ and Kenneth Ying, Ph.D. ${ }^{2}$
}

\author{
${ }^{1}$ BCI Engineers \& Scientists, Inc., Lakeland, Florida \\ ${ }^{2}$ Formerly BCI Engineers \& Scientists, Inc.; currently Bechtel Power Corporation, \\ Frederick, Maryland.
}

\begin{abstract}
This paper presents calculated wave heights and predicted erosion of upstream earth dam slopes at the L-8 Reservoir during Hurricane Jeanne in September 2004. The predictions are compared with actual measurements of slopes erosion following the hurricane. The methodology used in this study includes application of the USACE (2006) Coastal Engineering Manual method for wave run-up and overtopping computation, the SWAN wave model, and the SBEACH erosion model.

During Hurricane Jeanne, the north interior slopes of the perimeter dam experienced significant erosion due to wave action. Using hurricane parameters from NOAA, the SBEACH model was used to predict the final configuration of the eroded slopes. By comparing the predicted slope configuration to photographs taken following the hurricane, it was seen that the model output closely resembled the actual damaged slope profile. This comparison provided a calibration of the SBEACH model that was then used to design the final reservoir slopes and to determine recommended operating levels prior to the passage of future hurricanes. The analytical modeling tools used for the L-8 Reservoir study have recently been extended to an analysis of placing expendable soil over stair-step soil cement armoring on an upstream dam slope. The purpose of expendable soil is to allow small animal ingress and egress from the water reservoir.
\end{abstract}

\section{Introduction}

Computer programs were used to calculate wave heights and predict erosion of upstream earth dam slopes at the Loxahatchee Reservoir (also termed as L-8 Reservoir) during Hurricane Jeanne, which passed over the area near the site on September 26, 2004. The predicted erosion profiles were compared with actual measurements of slope erosion made following the hurricane.

The Loxahatchee Reservoir is a key component of the Comprehensive Everglades Restoration Plan (CERP), a Federal/State project to improve water quality and the distribution of fresh water in south Florida. It is located in western Palm Beach County, Florida. The reservoir was constructed during the period 2003-2008 in a previously mined limestone quarry consisting of seven interconnected cells that had been excavated to approximately El. $-4.26 \mathrm{~m}(-14 \mathrm{ft})$ (NAVD-1988). The reservoir was further deepened by dredging to El. $-12.8 \mathrm{~m}(-42 \mathrm{ft})$ to provide additional storage capacity up to $56,740,165 \mathrm{~m}^{3}$ (46,000 acre-feet). A perimeter dam to $\mathrm{El} .+7.01 \mathrm{~m}(+23 \mathrm{ft})$ surrounds the reservoir to provide overtopping protection as well as additional water storage. Normal operating level for the reservoir is $+4.57 \mathrm{~m}$ (+15 ft.), which is approximately natural ground level. 
The determination of dam freeboard and the assessment of potential erosion due to wave action have been major design issues of the CERP program. This is due to the major cost implications of higher dam heights as well as the high cost of armoring interior slopes against excessive erosion caused by wind-driven waves. Computations of wave height, wave setup, run-up, overtopping/overwash, and embankment erosion are used to meet these objectives. The methodology used in this study includes application of the USACE (2006) Coastal Engineering Manual method, the SWAN wave model, and the SBEACH erosion model. Hurricane data from NOAA's website were downloaded to provide the wind field data input to wave model. Sediment samples collected from the site were used in the erosion model. The post storm condition includes the rainfall data, water level records and photographs taken during the damage assessment after Hurricane Jeanne. These data were used to compare the simulation results produced by computer models.

\section{Methodology}

The purpose of the wave and erosion modeling is to estimate potential damage to the reservoir embankments caused by storm generated waves. The modeling effort involves the computation of wave heights in the reservoir and the calculation of cross-sectional erosions under various storm conditions. The SWAN model was used to compute the wave height distribution in the reservoir, which was then used in the SBEACH erosion model to calculate the cross-sectional profile changes for each embankment. In order to demonstrate that the results generated by these computer models are reliable, a real hurricane event was selected to test the model in the validation procedure. The wind data used in the wave modeling was obtained from the historical storm records. Hurricane Frances passed through the site in September 2004 and followed by Hurricane Jeanne 20 days later. The L-8 reservoir was gradually filled up by precipitations brought in by Hurricane Frances and its remnant up to about $3.05 \mathrm{~m}$ (10 ft) elevation. During the passage of Hurricane Jeanne, wind generated waves caused severe damages to the earth embankments in the reservoirs.

The models were set up to simulate the storm conditions of Hurricane Jeanne 2004 for embankment erosion. An initial calibration was performed for each model to test grid and sensitivity of parameters as part of the standard procedure for numerical modeling. The wave data had no observed values to be compared with but the erosion model had the cross sectional profiles to be compared with. Comparisons were made between the modeled results and the photo record of the wave damages taken after the storm. Details of comparisons will be explained later in this paper.

\section{Wave Model}

SWAN (imulating Waves Nearshore) model, developed by the Delft University of Technology (2006), is a two-dimensional model designed for the computation of wind generated waves in the coastal water bodies, lakes, reservoirs and estuaries. It is based on the discrete spectral action balance equation. The wave propagation is based on linear wave theory including the effect of currents. The processes of wind generation, dissipation and nonlinear wave-wave interactions are 
represented explicitly with third-generation formulations. For application, it considers factors such as wave propagation in time and space, shoaling, refraction due to current and depth, diffraction, frequency shifting due to currents and non-stationary depth, nonlinear three and four-wave interactions, white-capping, bottom friction, and depth-induced breaking, etc.

In this investigation, SWAN was used to calculate the significant wave heights, wave periods and wave directions for each storm's wind field. All of these outputs are required by the SBEACH erosion model for the computation of the crosssectional erosion. The input data for the SWAN model includes the 2-dimensional grid mesh, water depth, wind field distribution, friction coefficients, flow velocities, boundary conditions, and control parameters. Detailed description for the model application is to be presented later in this paper.

\section{SBEACH Model}

SBEACH model was developed by the U. S. Army Corps of Engineers (Larson and Kraus, 1989; Larson et al., 1990) for the simulating of beach profile change under the short crested wave conditions. This model was formulated based on a series of large wave tank tests and was validated by field data from the east and west coasts of the United States. The model assumes that the cross-sectional profile change is mainly governed by breaking of short-period waves. Both of the regular and irregular waves were considered. The formulation also included the factors like water depth, grain size, deep water wave steepness, the angle of avalanching of sediments and the transport rate coefficient. The avalanching angle and transport rate coefficient are basic calibration parameters determining the geometric and time scale of profile change. For the cross-sectional profiles with rock or non-erodible surface, SBEACH model was incorporated with the Non-erodible or Hard Bottom option (Larson and Kraus, 1998), which allows users to include non-erodible segments in the profiles. It also allows the seawall options, but only the Hard Bottom option was used for the current study.

For the L-8 reservoir, each embankment can be treated as one beach profile. The waves near the center of the reservoir are similar to the incident waves offshore of a beach profile. Since the site includes soil and rock layers on the embankments, both of the erodible and non-erodible segments are applied for the current study. Other parameters and procedures will be discussed in the next section.

\section{INPUT DATA}

\section{Storm Data}

For a hurricane, the wind field distribution is determined by the central pressure deficit, forward speed, radius to maximum winds, landfall point, track of the storm and the geometric formation of land. The last factor is not easy to implement and others can be accounted by several methods. Among these methods, the Holland (1980) wind field model is one of the best methods to calculate the hurricane wind distribution. The method has been broadly used to produce the wind field distribution for the modeling of storm surges and wind damage forecasts. For the historical storm 
data, the Holland model can be used to calculate the detailed wind field distribution wherever the historical data is not sufficient or available.

NOAA processes post storm wind data for each hurricane and publishes the results on their website (http://www.aoml.noaa.gov/hrd/data_sub/wind.html). In the current study, a historical storm is used for calibration and hypothetical storms are used for the operational runs. The historical hurricane wind field data from NOAA was applied to the validation model without any problem. For other runs after the validation run, the wind field distributions for hypothetical storms were calculated by using the Holland model. It should be pointed out that the wind speeds for the hypothetical storms could be overestimated. Holland model may overestimate wind speeds since it does not consider the land friction factor after storm moves into inland. For the current study, the existing estimated wind field data from the Holland wind field model were used. They give conservative design criteria, which will not cause any safety concern for the reservoir.

In September, 2004, Hurricane Jeanne passed through the northern part of the Palm Beach County, Florida. As a result, L-8 reservoir suffered a severe damage due to the wave erosion. The wind field data available from NOAA website for Hurricane Jeanne are shown in Figures 1(a) and 1(b). By applying these data, the time series of wind speed and wind direction at the L-8 site can be calculated as shown in Table 1 . Note that these wind speeds are the one-minute sustained wind speeds at ten meters above the ground or water surface. They were converted to 10 -minute sustained wind for the wave model. Data from NOAA include one complete wind field distribution for every three-hour interval along the storm track. Interpolations over space and time were necessary to derive the half-hour interval wind field data in between. The wind direction is measured counterclockwise from the east (positive $\mathrm{x}$-axis) to the direction which wind is blowing to. The present computation adapts the Cartesian convention for the SWAN wave model.

\section{Water Level Data}

The water level data in L-8 reservoir were affected by two factors: rainfall and pumping activity. The water levels of the reservoir are monitored by the South Florida Water Management District. The record of water levels before and after the arrival of the Hurricane Jeanne is listed in Table 2. All the water levels are referred to NAVD datum in feet. The recorded water levels, ranging from $1.52 \mathrm{~m}(5 \mathrm{ft})$ to $5.18 \mathrm{~m}$ (17ft) for various cells, on the day when the hurricane visited were selected for the model input. The local rain gage at the reservoir reported about nine inches of rainfall for Hurricane Jeanne. However, there was no data available for the day before the storm. Due to the remnant effect from Hurricane Frances prior to the landfall of Hurricane Jeanne, the exact starting water level in the reservoir for Hurricane Jeanne is not clear. It is assumed that the recorded water level on September 26, 2004 was the pool level in the reservoir when the maximum wind struck the L-8 site. 
Hurricane Jeanne 0600 UTC 26 SEP 2004 Max 1 -min sustained surtace vainds ikt

Valid for manne exposure over vater. open tertain exposure over land

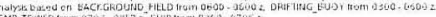

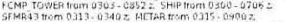

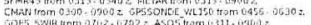

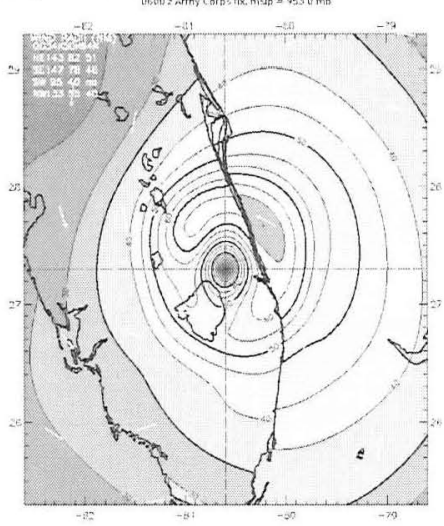

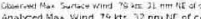

Figure 1(a). Hurricane Jeanne 2004 wind field data from NOAA/AOML.

Hu rricane Jeanne 0900 UTC 2.6 SEP 2004

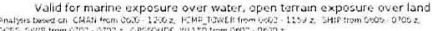

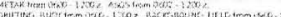

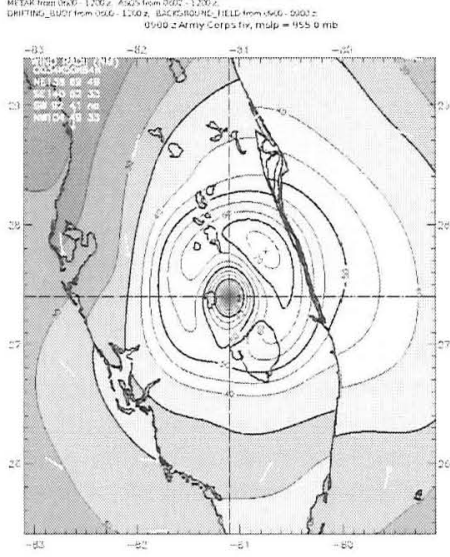

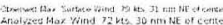

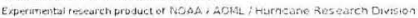

Figure 1(b). Hurricane Jeanne 2004 wind field data from NOAA/AOML. 
Table 1 . Wind field data for Hurricane Jeanne at the L-8 site.

\begin{tabular}{|c|c|c|c|c|c|}
\hline Time & $\begin{array}{c}\text { 10-min max. } \\
\text { sust. wind, } \mathbf{m} / \mathbf{s}\end{array}$ & $\begin{array}{c}\text { Wind Dir, } \\
\text { degrees }\end{array}$ & Time & $\begin{array}{c}\text { 10-min max. } \\
\text { sust. wind, } \\
\text { m/s }\end{array}$ & $\begin{array}{c}\text { Wind Dir, } \\
\text { degrees }\end{array}$ \\
\cline { 3 - 6 } 9/2521:00 & 14.4 & 283.7 & $9 / 263: 30$ & 35.9 & 331.9 \\
\hline 9/2521:30 & 15.6 & 284.6 & $9 / 264: 00$ & 36.1 & 342.1 \\
\hline 9/2522:00 & 16.7 & 285.7 & $9 / 264: 30$ & 35.8 & 352.3 \\
\hline 9/25 22:30 & 17.8 & 286.9 & $9 / 265: 00$ & 35.1 & 3.2 \\
\hline $9 / 2523: 00$ & 19.1 & 288.2 & $9 / 265: 30$ & 34.8 & 13 \\
\hline $9 / 2523: 30$ & 20.6 & 289.6 & $9 / 266: 00$ & 33.6 & 21.4 \\
\hline $9 / 260: 00$ & 22.3 & 291.3 & $9 / 266: 30$ & 32.0 & 27.6 \\
\hline $9 / 260: 30$ & 24.2 & 294.4 & $9 / 267: 00$ & 30.3 & 32.5 \\
\hline $9 / 261: 00$ & 26.2 & 298 & $9 / 267: 30$ & 28.9 & 37.7 \\
\hline $9 / 261: 30$ & 28.6 & 302.6 & $9 / 268: 00$ & 27.7 & 41.1 \\
\hline $9 / 262: 00$ & 30.9 & 307.9 & $9 / 268: 30$ & 26.4 & 44.5 \\
\hline $9 / 262: 30$ & 33.2 & 314.5 & $9 / 269: 00$ & 25.5 & 46.8 \\
\hline $9 / 263: 00$ & 34.7 & 322.6 & & & \\
\hline
\end{tabular}

Table 2. Water levels at the L-8 site during Hurricane Jeanne 2004.

\begin{tabular}{|l|l|l|l|l|l|l|l|}
\hline \multicolumn{1}{|c|}{ Date } & \multicolumn{1}{c|}{ Cell 1 } & \multicolumn{1}{c|}{ Cell 2 } & \multicolumn{1}{c|}{ Cell 3 } & Cell 4 & Cell 5 & Process & L-8 \\
\hline 9/15/2004 & 7.015 & 7.015 & 5.015 & 9.815 & 9.815 & 17.265 & 13.705 \\
\hline 9/16/2004 & 7.095 & 7.095 & 5.175 & 9.875 & 9.875 & 17.165 & 13.165 \\
\hline $9 / 17 / 2004$ & 7.155 & 7.155 & 5.415 & 9.915 & 9.915 & 17.065 & 12.565 \\
\hline $9 / 20 / 2004$ & 8.315 & 8.315 & 3.515 & 9.915 & 9.915 & 16.455 & 12.485 \\
\hline $9 / 21 / 2004$ & 8.555 & 8.555 & 3.715 & 10.135 & 10.135 & 17.005 & 13.065 \\
\hline $9 / 22 / 2004$ & 8.635 & 8.635 & 4.015 & 10.215 & 10.215 & 17.045 & 14.665 \\
\hline $9 / 23 / 2004$ & 8.715 & 8.715 & 4.315 & 10.215 & 10.215 & 17.005 & 14.565 \\
\hline $9 / 24 / 2004$ & 9.015 & 9.015 & 4.315 & 10.015 & 10.015 & 16.985 & 13.965 \\
\hline $9 / 26 / 2004$ & 10.365 & 10.365 & 5.365 & 10.225 & 10.225 & 17.115 & 15.495 \\
\hline $9 / 27 / 2004$ & 11.715 & 11.715 & 6.415 & 10.445 & 10.445 & 17.235 & 17.015 \\
\hline $9 / 28 / 2004$ & 13.835 & 13.835 & 8.315 & 10.655 & 10.655 & 17.365 & 16.965 \\
\hline $9 / 29 / 2004$ & 14.315 & 14.315 & 13.215 & 11.015 & 11.015 & 17.365 & 16.925 \\
\hline $9 / 30 / 2004$ & 14.435 & 14.435 & 14.435 & 11.375 & 11.375 & 17.525 & 17.165 \\
\hline
\end{tabular}

\section{Calibration Run and Result Comparison}

The model calibration focused on the cross-sectional erosion resulted from the wave. Since wind is the major driving force generating the waves which subsequently cause the erosion to the embankments, the calibration procedure emphasized on the relationship between the wind and the erosion result. Given the real wind data at the site, if the models can reproduce the real erosion conditions, then the models are ready to simulate the embankment erosion at the L- 8 site.

After obtaining the wind data, the parameters in SWAN wave model were adjusted for a hurricane wind condition as follows: Bottom friction was set at wind sea condition with bottom coefficient of $0.067 \mathrm{~m}^{2} / \mathrm{s}^{3}$ for the Jonswap bottom friction dissipation formulation; Wave and wave interaction was set at the three wave interaction mode for the shallow water condition; and Wave setup mode was turned 
on for the computation of surface water level build up due to the wave breaking and dissipation of wave energy.

The results of the wave model could be judged by comparing data from a similar water body. But this kind of data is not easy to find. Hence the wave outputs were only checked for the maximum values and the wave height distribution pattern. The maximum wave heights were expected to be much lower than the wave heights in the open sea due to the small volume of the water body in the reservoir relative to the ocean. For a storm with $128.7 \mathrm{~km} / \mathrm{hr}(80 \mathrm{mph})$ wind, the wave heights in the open sea range from 7 to 14 meters according to the data measured by the National Data Buoy Center (NDBC) in the Gulf of Mexico and the Atlantic Ocean (http:/seaboard. ndbc.noaa.gov/hmd.shtml). The buoys used by NDBC are located in the open sea with water depth more than 1,000 meters. The behavior of waves in the deep ocean is much different from the wave pattern in a small inland water body. The computed maximum wave heights in the L-8 reservoir for $128.7 \mathrm{~km} / \mathrm{hr}(80 \mathrm{mph})$ wind are about 1.2 meters. With the water depth ranging from 14.3 to 17.3 meters in the reservoir and the surface area less than one square kilometer in each cell, the wave heights are limited by the dimension of the wind fetch. Using the Figure 3-23 in the Shore Protection Manual (1984), the significant wave height for the wind fetch of $2 \mathrm{~km}$ long and $128.7 \mathrm{~km} / \mathrm{hr}(80 \mathrm{mph})$ wind speed is 1.25 meters. This indicates that the wave height of 1.2 meters given by the SWAN model seems reasonable for the $128.7 \mathrm{~km} / \mathrm{hr}$ wind.

The output from the SWAN wave model provides the wave input to the SBEACH model. SBEACH requires wave height, wave period, wave direction, water level, wind speed, and wind direction. Other than the wind and wave data, SBEACH requires the cross-sectional profile of the embankment, physical properties of the sediment, and the water temperature. The cross-sectional profile includes the erodible and non-erodible segments of the embankment. In the input data, the rock bed and cemented surface are treated as non-erodible surfaces and others are erodible. The sediment properties include the medium grain size and the avalanching angle of the cross-section. For the L- 8 site, the medium size is $0.319 \mathrm{~mm}$ and the avalanching angle is determined to be 60 degrees due to the high bonding force for the compacted dry material on site. The water temperature is taken to be $28^{\circ} \mathrm{C}$ for the local climate condition. The SBEACH model produces results in the graphic and tabular formats. For Hurricane Jeanne, the wave model output is shown in Figure 2. The simulated cross sectional profiles for Phase One embankment before and after the storm are presented in Figure 3. Note that the horizontal scale of the model output is compressed in order to fit in the paper size for the plot. Figure 4 shows the photos of Phase One embankment taken after Hurricane Jeanne. For comparison, the model output is stretched to get the right horizontal scale as shown in Figure 5. By comparing the model output figure to the photos, it can be seen that the model output closely resembles the real damaged profile with similar magnitude of slope angles on the upper part of the embankment. 


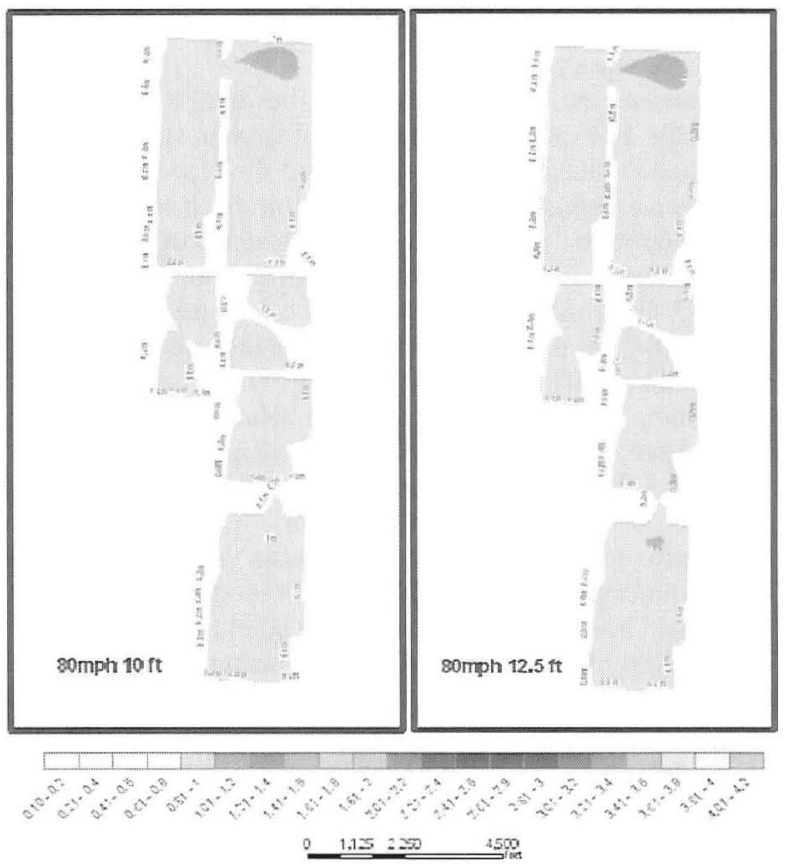

Figure 2. Significant wave height distribution in the PBA reservoir.

Old Phase One embankment

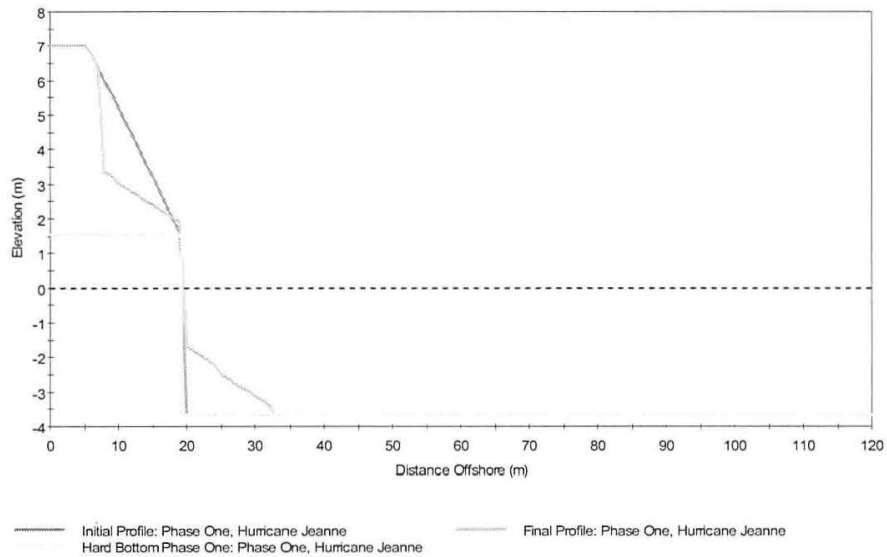

Figure 3. SBAECH erosion model output for Phase One embankment after Hurricane Jeanne. 


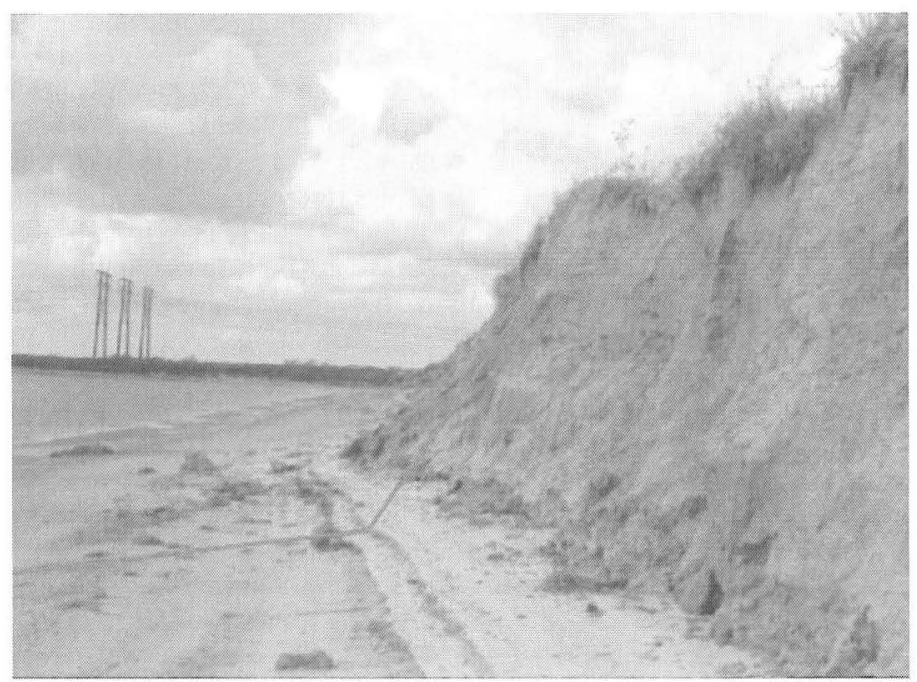

Figure 4. Picture of Phase One embankment after Hurricane Jeanne.

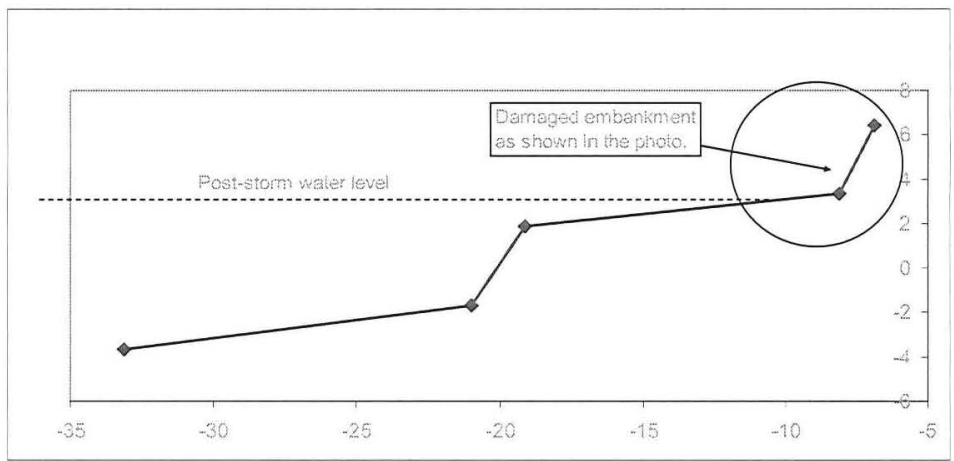

Figure 5. Model result with corrected horizontal and vertical scales for the damaged embankment cross section. 
After the validation, a series of modeling runs were made to evaluate the wave and erosion conditions in the reservoir for various storms. The range of storm wind speeds varies from the $112.6 \mathrm{~km} / \mathrm{hr}(70 \mathrm{mph})$ to $321.8 \mathrm{~km} / \mathrm{hr}(200 \mathrm{mph})$, which covers Category 1 to 5 hurricanes and the DCM-2 criteria (South Florida Water Management District, 2005). For each storm, the pool levels from $1.52 \mathrm{~m}(5 \mathrm{ft})$ to $5.03 \mathrm{~m}(16.5 \mathrm{ft})$ were used to simulate the operational mode of the reservoir. The soil volume loss caused by erosion at each embankment was calculated for each storm to evaluate the degree of possible damage. The quantified values of erosion are used as the reference to generate the operational guidance to minimize the damage by lowering water to the optimal level in the reservoir prior to the arrival of each storm.

The analytical modeling tools for this study have been extended to analysis of placing expendable soil over stair-step soil cement armoring on an upstream dam slope. The purpose of expendable soil is to allow small animals (mainly turtles and fledging birds) ingress and egress from the water reservoir with the stair-step type embankment. The models were applied to evaluate the mitigation of animal entrapment in reservoirs with stair-steps armoring appears feasible by using an expendable soil layer on top of the stair-steps to form a smooth slope. The model results show that the soil layer can be washed away by waves to expose the stair-steps within a short time during a major hurricane. The recommended construction material for this expendable layer is a non-cohesive sand, gravel, or combination thereof.

\section{Summary}

SWAN Model and SBEACH Model were applied to simulate the cross sectional erosion for the embankments in the L-8 Reservoir. The post storm wind data for Hurricane Jeanne were selected to be the input to the wave model. The wave output from SWAN model was then applied to the SBEACH erosion model along with the wind data and the soil properties. The results produced by this procedure closely resembled the real erosion damage caused by Hurricane Jeanne. The procedure shows that the models can be applied to simulate the future wave erosion in the L- 8 Reservoir. Further simulations were carried for wind speeds from $70 \mathrm{mph}$ to 200 mph with operational water levels ranging from $5 \mathrm{ft}$ to $16.5 \mathrm{ft}$ in the reservoir. The potential damage measured in eroded soil volume to each embankment was also estimated for each storm scenario. The results produced by the models provided significant information for the reservoir operation to minimize the potential damages caused by the hurricanes.

\section{REFERENCES}

1. Delft University of Technology (2006). "SWAN Technical Documentation", SWAN Cycle II Version 40.51, Delfeet, The Netherlands.

2. Holland, G. J. (1980). "An Analytic Model of the Wind and Pressure Profiles in Hurricanes," Mon. Wea. Rev., Vol 108, pp 1212-1218.

3. Larson, M. and N.C. Kraus (1989). "SBEACH: Numerical Model for Simulating Storm-Induced Beach Change; Report 1: Empirical Foundation 
and Model Development." U.S. Army Corps of Engineers, Technical Report CERC-89-9, Washington, D.C.

4. Larson, M., N. C. Kraus and R. Byrnes (1990). "SBEACH: Numerical Model for Simulating Storm-Induced Beach Change; Report 2: Numerical Formulation and Model Tests." U.S. Army Corps of Engineers, Technical Report CERC-89-9, Washington, D.C.

5. Larson, M. and N.C. Kraus (1998). "SBEACH: Numerical Model for Simulating Storm-Induced Beach Change; Report 5: Representation of Nonerodible (Hard) Bottoms." U.S. Army Corps of Engineers, Technical Report CERC-89-9, Washington, D.C.

6. South Florida Water Management District (2005), "Design Criteria Memorandum: DCM-2 Revision 001.00. Wind and Precipitation Design Criteria for Freeboard," Acceler8 Ref \#: P 599, 2-3-056

7. U.S. Army Corps of Engineers (2006). "Coastal Engineering Manual, "Part II, EM-1110-2-1100.

8. U.S. Army Corps of Engineers (1984), "Shore Protection Manual," Volume I, Coastal Engineering Research Center. 